\title{
Cross-border e-commerce as a foreign market entry mode among SMEs: the relationship between export capabilities and performance
}

\author{
Fabio Cassia \\ Department of Business Administration, University of Verona, Verona, Italy, and \\ Francesca Magno \\ Department of Management, University of Bergamo, Bergamo, Italy
}

\begin{abstract}
Purpose - Although cross-border e-commerce has become increasingly popular among small and mediumsized enterprises as a foreign market entry mode, research on the determinants of its success is scarce. Drawing on the resource-based view, this study aims to examine the relationship between a firm's information technology, international marketing and export operations capabilities and its cross-border e-commerce strategic and financial performance.

Design/methodology/approach - Partial least squares structural equation modeling was used to analyze data from a sample of Italian exporters in the food and beverage industry.

Findings - The results highlight the mixed effects of information technology, international marketing and export operations capabilities on both e-commerce strategic and financial performance. Moreover, the use of third-party e-commerce platforms reduces the effect of exporters' information technology capabilities on their e-commerce financial performance.

Research limitations/implications - The majority of exporters in this study had implemented crossborder e-commerce only recently; hence, longitudinal data on the success factors of e-commerce are not available.

Practical implications - While cross-border e-commerce may work as an accelerator of the overall export performance, export managers are urged to approach it strategically with a clear medium-term view to develop the required capabilities.

Originality/value - This study was one of the first to examine the drivers of small and medium-sized exporters' cross-border e-commerce performance. Moreover, unlike most previous analyzes, it focused on e-commerce as a foreign market entry mode rather than a supplement to offline exporting activities.
\end{abstract}

Keywords Capabilities, Entry mode, Resource-based view, Cross border e-commerce,

Export management

Paper type Research paper

(C) Fabio Cassia and Francesca Magno. Published by Emerald Publishing Limited. This article is published under the Creative Commons Attribution (CC BY 4.0) licence. Anyone may reproduce, distribute, translate and create derivative works of this article (for both commercial and noncommercial purposes), subject to full attribution to the original publication and authors. The full terms of this licence may be seen at http://creativecommons.org/licences/by/4.0/legalcode 
RIBS

32,2

\section{Introduction}

Recent advances in information technologies (IT) have enabled exporters to improve their efficiency, effectiveness and overall performance in foreign markets (Ferreira et al., 2021; Goldman et al., 2020; Alarcón-del-Amo et al., 2018; Watson et al., 2018). In particular, digitalization is fundamental in the internationalization of small and medium-sized enterprises (SMEs) (Morais and Ferreira, 2020). Several studies have specifically examined how exporters can leverage the internet to enhance their international activities (Alarcóndel-Amo et al., 2018; Bianchi et al., 2017; Glavas et al., 2019; Prasad et al., 2001). Extensive knowledge is available on how the internet can facilitate foreign market analysis, reduce psychic distance, accelerate market entry, enrich internationalization capabilities and support customer relationship management (Glavas et al., 2017; Hooper and Holtbrügge, 2020; Mathews et al., 2016; Sheth and Sharma, 2005; Yamin and Sinkovics, 2006). However, the majority of this research views the internet as a complementary tool to integrate and improve exporters' marketing strategies rather than as a direct sales channel (Mathews et al., 2016; Sinkovics et al., 2013).

Nonetheless, official statistics indicate that cross-border e-commerce - the sale of goods and services conducted over the internet to foreign customers - is rapidly growing. According to estimates from the most recent United Nations Conference on Trade and Development (UNCTAD, 2020), revenue from cross-border business-to-consumer (B2C) e-commerce in 2018 amounted to $\$ 404 \mathrm{bn}$ and the coronavirus crisis has further contributed to its growth. In some countries, cross-border e-commerce is significantly high. For example, in 2019, cross-border e-commerce made up 7\% of all Italian exports of B2C products (ICEITA, 2020). This has arisen from the fact that $99.9 \%$ of Italian firms are SMEs (1-249 employees) and $94.9 \%$ are microenterprises (1-9 employees) and their access to foreign markets is being accelerated by cross-border e-commerce (ICE-ITA, 2020). Some analyzes even indicate that cross-border e-commerce is the most effective channel through which to enter specific export markets such as China (Giuffrida et al., 2017).

Although an increasing number of exporters are adding cross-border e-commerce to their foreign market entry modes, research on this issue is still in its infancy (Qi et al., 2020; Watson et al., 2018; Zhu et al., 2019). In particular, knowledge of the drivers of small and medium-sized exporters' cross-border e-commerce performance is limited to the analysis of their digital marketing tactics (Goldman et al., 2020). This study aims to address this gap by suggesting a model that draws on export capabilities (Morgan et al., 2012). The capabilities framework has been extensively applied in international management to explain firms' foreign market performance (Efrat et al., 2018; Morgan et al., 2018; Morgan et al., 2004). Building on this stream of research, we develop and test a model that includes three export capabilities - IT capabilities, international marketing capabilities and export operations capabilities - as antecedents of both market and financial performance of cross-border e-commerce. In addition, the model includes the moderating role of the use of third-party platforms (e.g. Amazon or Alibaba) by SMEs to avoid the need to develop their own e-commerce websites. In fact, the use of third-party e-commerce platforms, which offer a range of services to exporters, is rapidly growing (Deng and Wang, 2016; Wang et al., 2020). Therefore, the relationship between a firm's internal export capabilities and its cross-border e-commerce performance may be weakened by the use of third-party platforms.

The findings of this study contribute to the export management research by clarifying the links between export capabilities and cross-border e-commerce performance for small and medium-sized exporters. In addition, this research provides actionable insights for SMEs interested in adopting cross-border e-commerce as a foreign market entry mode (Qi et al., 2020). 
The remainder of this paper is structured as follows. First, we introduce the background for this study. Second, we develop our model and hypotheses. Third, we describe the research methods and present the results. Finally, we discuss the implications of the findings, the limitations of the research and opportunities for future studies.

\section{Background and research model}

Cross-border e-commerce

The continual development of information and communication technologies has dramatically expanded the opportunities for cross-border e-commerce as a new international market entry mode (Deng and Wang, 2016; Qi et al., 2020; Watson et al., 2018). The concept of e-commerce has not been univocally defined in the international management literature. Some researchers ( Gregory et al., 2007) view e-commerce from a broad perspective that includes the various effects of information and communication technologies on a firm's international business. According to this perspective, e-commerce encompasses activities such as "providing online product catalogue, online promotion of products, online ordering, online payment, salesperson online access, e-procurement, participation in the electronic marketplace and e-fulfilment" (Gregory et al., 2019, p. 151). Other authors take a narrower view of e-commerce to include only online sales (Alarcón-del-Amo et al., 2018; Giuffrida et al., 2017). We adopt the second perspective, which is consistent with the official definition of e-commerce from the Organisation for Economic Co-operation and Development (2013):

An e-commerce transaction is the sale or purchase of goods or services, conducted over computer networks by methods specifically designed for the purpose of receiving or placing of orders. The goods or services are ordered by those methods, but the payment and the ultimate delivery of the goods or services do not have to be conducted online. [...] To be included are orders made over the Web [... T To be excluded are orders made by telephone calls, facsimile or manually typed eail.

Drawing on this definition and on UNCTAD (2017) guidelines, we conceptualize crossborder e-commerce as the sale of goods and services to foreign customers conducted over the internet. We focus specifically on the use of B2C cross-border e-commerce as a foreign market entry mode for exporters (Gabrielsson and Gabrielsson, 2011). As highlighted by Watson et al. (2018), firms are more likely to embrace this channel when intermediaries in the foreign market are less powerful, reducing the risk of multichannel conflicts and retaliation.

\section{Research model}

Similar to other foreign market entry modes, cross-border e-commerce requires exporters to possess specific capabilities (Goldman et al., 2020; Sinkovics et al., 2013). While knowledge of the export capabilities required for cross-border e-commerce is limited, there is extensive evidence on the relationship between export capabilities and foreign market performance (Andersen, 1997; Chen et al., 2016). This stream of studies draws on the resource-based view (Barney, 1991) and embraces the idea that capabilities are "complex bundles of skills and accumulated knowledge, exercised through organizational processes, that enable firms to coordinate activities and make use of their assets" (Day, 1994, p. 38). Many export capabilities have been identified in the literature, which also highlights the direct relationships between some capabilities owned by a firm and the entry modes it selects (Morgan et al., 2018). Given the absence of prior research on cross-border e-commerce, we identified the most relevant capabilities for our model as follows. After extensively reviewing the international management literature related to capabilities and a recent UNCTAD (2017) report on digitalization, trade and development, we conducted an
Cross-border e-commerce 
RIBS

32,2

exploratory inquiry to capture export managers' views on the topic (Shah and Corley, 2006). The UNCTAD (2017) report suggests that firms using e-commerce platforms may start exporting once they are discovered by a foreign buyer; however, their long-term success requires specific capabilities related to relevant technologies, conformity with legal and fiscal requirements in the target markets, access to logistics and the effective management of requests by and relationships with foreign customers.

For our exploratory inquiry, we contacted 11 export managers (drawn from our personal networks) with experience in cross-border B2C e-commerce and asked each of them to elicit and discuss relevant capabilities. The profiles of these export managers are shown in Table 1.

We adopted the long interview method and used general and non-directive interview questions (McCracken, 1988). Most interviews were conducted using video conferencing software. The exploratory inquiry was conducted to obtain practitioners' perspectives on the most important export capabilities needed to successfully conduct cross-border e-commerce, providing valuable inputs to frame our research.

From this process, we identified three capabilities needed for successful B2C cross-border e-commerce - IT capabilities, international marketing capabilities and export operations capabilities - and included them in our research model as antecedents of performance (Figure 1). The model distinguished between two types of cross-border e-commerce performance outcomes: strategic performance and financial performance. Previous researchers have strongly recommended making this distinction to gain an in-depth appreciation of the effects of capabilities (Efrat et al., 2018). Strategic performance is a subjective measure of the degree to which export goals are achieved, while financial performance in an objective indicator of outcomes (Gregory et al., 2019; Morgan et al., 2012). The relationships between a firm's export capabilities and its strategic and financial export performance have been widely documented (Chen et al., 2016; Morgan et al., 2018). Hereafter, the research hypotheses are developed.

Information technologies capabilities and performance. A firm's IT capabilities reflect its ability to integrate its IT and digital resources and knowledge to pursue its cross-border e-commerce goals (Bianchi and Mathews, 2016; Gregory et al., 2019; Mathews et al., 2016). These capabilities arise from an organization's technology and market orientation

\begin{tabular}{|c|c|c|c|c|c|}
\hline \multirow[b]{2}{*}{ Participant } & \multirow[b]{2}{*}{ Main firm product offering } & \multicolumn{3}{|c|}{ Experience (years) } & \multirow{2}{*}{$\begin{array}{l}\text { Previous } \\
\text { training on } \\
\text { IT or digital } \\
\text { marketing }\end{array}$} \\
\hline & & $\begin{array}{c}\text { Export } \\
\text { management }\end{array}$ & $\begin{array}{l}\text { Current } \\
\text { company }\end{array}$ & $\begin{array}{l}\text { Cross-border } \\
\text { e-commerce }\end{array}$ & \\
\hline 1 & Jam and juices & 6 & 4 & 2 & Yes \\
\hline 2 & Baked goods & 5 & 3 & 1 & Yes \\
\hline 3 & Wine & 19 & 9 & 7 & No \\
\hline 4 & Wine & 16 & 10 & 8 & Yes \\
\hline 5 & Olive oil & 12 & 11 & 4 & Yes \\
\hline 6 & Rice/other cereals & 25 & 25 & 5 & No \\
\hline 7 & Cheese & 7 & 5 & 4 & No \\
\hline 8 & Wine & 3 & 3 & 3 & Yes \\
\hline 9 & Pastry products & 14 & 7 & 1 & Yes \\
\hline 10 & Sauces/canned food & 8 & 8 & 3 & No \\
\hline 11 & Wine & 11 & 11 & 6 & No \\
\hline
\end{tabular}

Table 1.

Export manager profiles 


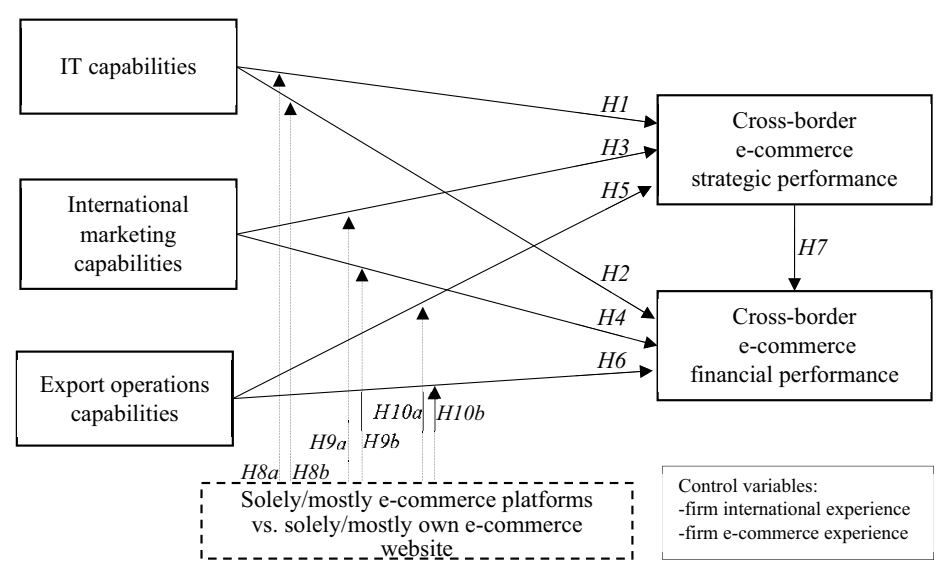

Cross-border e-commerce

(Trainor et al., 2011). Research has consistently shown that IT capabilities are positively related to the achievement of strategic objectives in the target market (Gregory et al., 2019) and financial performance (Bianchi et al., 2017). Thus, we hypothesize that:

H1. IT capabilities are positively related to cross-border e-commerce strategic performance.

H2. IT capabilities are positively related to cross-border e-commerce financial performance.

International marketing capabilities and performance. A firm's international marketing capabilities refer to its ability to integrate available knowledge and resources to interact with, understand and satisfy the needs of foreign customers (Morgan et al., 2018). Previous research has revealed a positive link between an exporter's marketing capabilities and its strategic effectiveness (i.e. the degree to which export markets respond to the exporter's actions) (Morgan et al., 2012). In addition, marketing capabilities - such as the ability to manage relationships with foreign customers - are antecedents of exporters' financial performance (Jin and Cho, 2018; Kaleka, 2012). Other studies have shown that marketing capabilities simultaneously influence exporters' strategic and financial performance (Murray et al., 2011). Hence, we hypothesize that:

H3. International marketing capabilities are positively related to cross-border e-commerce strategic performance.

H4. International marketing capabilities are positively related to cross-border e-commerce financial performance.

Export operations capabilities and performance. A firm's export operations capabilities refer to its ability to integrate available knowledge and resources to effectively conform to the legal and fiscal requirements of target markets (e.g. import duties and taxes, import licenses, import documentation requirements and foreign contracts) and manage logistics (e.g. transport mode and insurance) (UNCTAD, 2017). While logistical aspects have been discussed in detail by previous authors (Giuffrida et al., 2017), the legal and fiscal aspects have been largely overlooked (Ellram, 1991). However, as shown by UNCTAD (2017) and confirmed by our exploratory inquiry, these aspects are pivotal to the success of cross- 
RIBS

32,2

272

border e-commerce. In particular, export operations capabilities are needed for products that require protective measures during transportation and for which regulations vary markedly from one country to another (e.g. food and alcoholic beverages). Given the lack of available research, we draw on similarities between these capabilities and specialized export marketing capabilities - defined as "export marketing program-related processes needed to implement export venture marketing strategies" (Morgan et al., 2012, p. 274) - to establish our hypotheses. Therefore, we consider export operations capabilities as the technical capabilities needed by a firm to implement export operations. Building on research findings with respect to specialized export marketing capabilities (Gregory et al., 2019), we hypothesize that:

H5. Export operations capabilities are positively related to cross-border e-commerce strategic performance.

H6. Export operations capabilities are positively related to cross-border e-commerce financial performance.

Cross-border e-commerce strategic and financial performance. Previous research highlights the importance of adopting multiple measures to evaluate exporter performance in foreign markets (Morgan et al., 2004; Zou et al., 1998). Researchers have emphasized the importance of using both strategic (subjective) and financial (objective) performance indicators (Efrat et al., 2018). International management research has consistently reported the existence of positive and significant relationships between the two types of performance measures (Ren et al., 2009; Spyropoulou et al., 2018). Even if the export management research has not specifically investigated e-commerce performance, we suggest that previous findings related to foreign marketing performance can be extended to the e-commerce entry mode (Gregory et al., 2019; Murray et al., 2011). Thus, we hypothesize that:

H7. Cross-border e-commerce strategic performance is positively related to cross-border e-commerce financial performance.

The role of e-commerce platforms. E-commerce platforms or marketplaces such as Amazon and Alibaba have gained a prominent position in cross-border e-commerce (Watson et al., 2018). Exporters must make substantial efforts to establish and operate their own e-commerce websites and develop the related capabilities; thus, the use of third-party e-commerce platforms can accelerate their cross-border e-commerce adoption and performance (Deng and Wang, 2016; Wang et al., 2020). In particular, these platforms often provide exporters with enabling services such as technological tools to analyze customer information (Wang et al., 2016), which may contribute to reducing the distance between home and host countries (Moalla and Mayrhofer, 2020). Moreover, established platforms such as Amazon typically offer payment and logistics services, dramatically facilitating cross-border e-commerce management for SMEs. Thus, when an exporter decides to use an established platform to conduct cross-border e-commerce, the effects of its internal capabilities on its performance may be weaker. In other words, we suggest that in these cases, platforms may act as partial substitutes for exporter capabilities, negatively moderating the effects of capabilities on export performance. Therefore, we hypothesize that:

H8. The sole or main use of e-commerce platforms negatively moderates the relationship between IT capabilities and cross-border e-commerce strategic ( $H 8 a)$ and financial $(H 8 b)$ performance. 
H9. The sole or main use of e-commerce platforms negatively moderates the relationship between international marketing capabilities and cross-border e-commerce strategic (H9a) and financial (H9b) performance.

Cross-border e-commerce

H1O. The sole or main use of e-commerce platforms negatively moderates the relationship between export operations capabilities and cross-border e-commerce strategic $(H 1 O a)$ and financial $(H 1 O b)$ performance.

\section{Methods}

A questionnaire was distributed among a sample of Italian firms in the food and beverage industry that were engaged in cross-border e-commerce. According to the Italian Trade Agency (ICE-ITA, 2020), food and beverage goods, together with fashion goods, account for $77 \%$ of Italian cross-border e-commerce B2C exports. A list of 497 Italian firms in the food and beverage industry was compiled by manually reviewing four cross-border e-commerce platforms (Amazon, eBay, Eataly and Alibaba) and conducting Google searches for Italian food and beverage exporters using their own e-commerce platforms. We began with thirdparty e-commerce platforms because, according to the Italian Trade Agency, more than $90 \%$ of Italian B2C e-commerce is generated through these platforms. Because $99.9 \%$ of Italian firms are SMEs, we sent invitations to all 497 firms, then excluded large firms (those reporting 250+ employees). Contact details of exporters listed in the platforms were obtained by visiting their websites. An invitation to complete an online questionnaire was then sent by email.

The questionnaire was structured into two sections. The first section included questions about the firm's profile and its experience with international markets in general (exported goods, entry modes, number of years of experience with foreign markets, number of served markets, number of years of experience with cross-border e-commerce, people in charge of managing the firm's cross-border e-commerce channel, role of the respondent and other firm details). The second section included the measures of all constructs in the model.

The three capabilities (IT capabilities, international marketing capabilities and export operations capabilities) were modeled as formative constructs. A list of items for the IT and international marketing capabilities was initially created by consulting available studies (Bianchi et al., 2017; Gregory et al., 2019; Mathews et al., 2016; Morgan et al., 2018). Because the items had not been originally developed for cross-border e-commerce, their relevance to the specific research context was discussed during the abovementioned pilot study with the 11 export managers. For the export operations capabilities, items were directly generated during the pilot study because no previous operationalization was available. As a result of this process, the three constructs were measured using the items shown in Table 3. Following established practice (Murray et al., 2011), respondents were asked to rate each item relative to their firms' major competitors on a five-point scale $(1=$ very poor to $5=$ outstanding).

Strategic performance reflects the extent to which exporters' goals have been met. This construct was modeled as formative and included two items taken from Gregory et al. (2019), which were measured using a five-point scale $(1=$ not achieved at all to $5=$ completely achieved). Similar to the measure used by Gregory et al. (2019) for overall financial performance in foreign markets, we operationalized cross-border e-commerce financial performance using cross-border e-commerce sales as a percentage of total export sales. In addition, with the aim of ensuring convergent validity, each formative construct also included a global item summarizing the essence of the construct (Hair et al., 2017). 
RIBS

32,2

274

Finally, the moderating variable was operationalized as dichotomous: cross-border e-commerce executed solely or mainly through a firm's own website versus cross-border e-commerce executed solely or mainly through third-party e-commerce platforms. Based on previous findings that an exporter's international experience may influence its approach to e-commerce (Sinkovics et al., 2013), two control variables were also included for each firm: the number of years of international experience and the number of years of cross-border e-commerce experience, respectively.

Overall, we received 117 questionnaires, 16 of which were excluded from the analysis. In 14 of the excluded questionnaires, respondents reported that they did not directly manage the cross-border e-commerce of their products - in most cases, products were purchased by domestic intermediaries, who then autonomously exported them using e-commerce (indirect exports) (Hessels and Terjesen, 2010). Two others were excluded because the firm had 250+ employees. The final sample comprised 101 exporters, giving a response rate of $20.3 \%$. While not large, the sample size was adequate to analyze the data using partial least squares structural equation modeling (PLS-SEM), which requires samples to be at least 10 times the largest number of formative indicators used to measure a construct or the number of structural paths directed at a particular construct (Hair et al., 2017). The absence of nonresponse bias was checked by using $t$-tests to compare early and late respondents on several variables (Armstrong and Overton, 1977).

Table 2 presents the roles of respondents and summarizes the main characteristics of firms in the sample. For all firms, cross-border e-commerce was one of several entry modes, with distributors and importers being the other two main export channels. In addition, all firms had at least some previous international experience when they decided to adopt crossborder e-commerce. Finally, experience with cross-border e-commerce was limited, revealing that its adoption is still in the early stages.

Data were analyzed using PLS-SEM, which is gaining popularity as an alternate tool to covariance-based structural equation modeling when there is little a priori knowledge on the topic and the study is exploratory rather than confirmatory (Hair et al., 2011, 2019). Moreover, PLS-SEM is particularly useful when the sample size is small, which was the case in our research because of the small number of food and beverage firms that have embraced cross-border e-commerce (Hair et al., 2017). Finally, PLS-SEM is recommended when using formative constructs (Hair et al., 2019). For these reasons, PLS-SEM is frequently applied in international business research (Magnani and Zucchella, 2020; Richter et al., 2016). The analysis was conducted using the software SmartPLS 3 (Ringle et al., 2015).

\section{Results}

Measurement model assessment

Apart from cross-border e-commerce financial performance and the moderating variable (solely/mainly own e-commerce website versus solely/mainly third-party platform), all constructs were formatively measured. Therefore, the measurement model was evaluated based on convergent validity, indicator collinearity and statistical significance and relevance of indicator weights (Hair et al., 2017, 2020). To assess convergent validity, we used redundancy analysis to examine the correlations of each construct with an alternate single-item measure able to capture the essence of the same construct (Hair et al., 2019). For all constructs, correlations higher than 0.70 indicated that convergent validity had been met (Hair et al., 2017). Indicator collinearity was analyzed by inspecting variance inflation factors, all of which were well-below the cutoff value of 5, confirming that collinearity was not an issue (Hair et al., 2017). Finally, the statistical significance and relevance of indicator weights was examined. Bootstrapping (5,000 subsamples, bias-corrected and accelerated 


\begin{tabular}{|c|c|c|}
\hline Variable & Frequencies $(n=101)$ & Cross-border \\
\hline \multicolumn{3}{|l|}{ Role of the respondent } \\
\hline Marketing manager & 26 & \\
\hline Sales/export manager & 24 & \\
\hline CEO (entrepreneur) & 23 & \\
\hline Sales administration manager & 18 & \\
\hline Other roles (including IT manager) & 10 & 275 \\
\hline \multicolumn{3}{|l|}{ Entry mode } \\
\hline Cross-border e-commerce & 101 & \\
\hline Importer & 72 & \\
\hline Distributor & 66 & \\
\hline Trading company & 14 & \\
\hline Broker & 11 & \\
\hline Export consortium & 10 & \\
\hline Other modes & 60 & \\
\hline \multicolumn{3}{|l|}{ Served markets (number of countries) } \\
\hline 1 & 2 & \\
\hline $2-5$ & 39 & \\
\hline $6-10$ & 25 & \\
\hline $11-20$ & 10 & \\
\hline $20+$ & 25 & \\
\hline \multicolumn{3}{|c|}{ Experience with foreign markets (number of years) } \\
\hline$<10$ & 36 & \\
\hline $11-20$ & 25 & \\
\hline $21-30$ & 24 & \\
\hline $30+$ & 16 & \\
\hline \multicolumn{3}{|c|}{ Experience with cross-border e-commerce (number of years) } \\
\hline$<2$ & 23 & \\
\hline 3 & 34 & \\
\hline 4 & 22 & \\
\hline $5+$ & 22 & $\begin{array}{r}\text { Table } 2 . \\
\text { Descrintive statictics }\end{array}$ \\
\hline Note: $\mathrm{CEO}=$ Chief executive officer & & of the sample \\
\hline
\end{tabular}

bootstrap, two-tailed test) revealed that not all indicator weights were statistically significant. Following Hair et al. (2017), we then considered each formative indicator's absolute contribution to its constructs given by the formative indicator's outer loading. All outer loadings were significant and much higher than the cutoff value of 0.5 . Therefore, all indicators were retained.

\section{Structural model assessment}

After checking the validity and reliability of construct measures, we estimated the path model via bootstrapping (5,000 subsamples, bias-corrected and accelerated bootstrap, twotailed test). First, we examined the structural model for collinearity for each set of predictor constructs, finding that all variance inflation factor values were below the suggested level of 5 . Next, we analyzed the model's in-sample predictive power by inspecting the coefficient of determination $\left(R^{2}\right)$ for cross-border e-commerce strategic performance and financial performance. Both constructs had acceptable values (0.348 and 0.440 , respectively), which were higher than the average value of 0.33 found in meta-analyzes of international business 
IT capabilities (formative measure) ${ }^{\mathrm{a}}$

$\begin{array}{ll}\text { ITC1. Use e-commerce and internet-based technologies } & 0.504\end{array}$

$\begin{array}{ll}\text { ITC2. Manage digital marketing tools } & 0.568\end{array}$

International marketing capabilities (formative measure) ${ }^{\mathrm{a}}$

$\begin{array}{ll}\text { IMC1. Understand foreign customers' needs } & 0.342\end{array}$

$\begin{array}{ll}\text { IMC2. Manage relationships with foreign customers } & 0.381\end{array}$

$\begin{array}{ll}\text { IMC3. Apply international marketing strategies effectively } & 0.395\end{array}$

Export operations capabilities (formative measure) ${ }^{\mathrm{a}}$

EOC1. Manage conformity with foreign markets' legal and fiscal requirements 0.419

EOC2. Manage international logistics (transport mode selection, documentation, insurance, etc.) 0.625

Cross-border e-commerce strategic performance (formative measure) ${ }^{\mathrm{b}}$

$\mathrm{SP} 1$. Sales objectives of cross-border e-commerce

SP2 Other strategic objective of cross-border e-commerce (e $\mathrm{g}$ access to new foreign markets)

Cross-border e-commerce financial performance ${ }^{c}$

Cross-border e-commerce sales as a percentage of total export sales

Use of e-commerce platforms ${ }^{\mathrm{c}}$

$1=$ cross-border e-commerce executed solely or mainly through a firm's own website; $2=$ cross-

Table 3.

Construct measures

and indicator weights
Notes: 'Competences relative to their firms' major competitors on five-point scales $(1=$ very poor; $5=$ outstanding). 'btrategic performance related to the objectives of the cross-border e-commerce $(1=$ not achieved at all; $5=$ completely achieved). ${ }^{\text {cSingle-item measures }}$

studies (Richter et al., 2016). We then used the blindfolding procedure to calculate the $\mathrm{Q}^{2}$ value (Geisser, 1974; Stone, 1974), which is a further indicator of a path model's predictive accuracy (Hair et al., 2017). The $\mathrm{Q}^{2}$ values for cross-border e-commerce strategic performance and financial performance were 0.197 and 0.370 , respectively, revealing acceptable predictive relevance of the PLS path model (Hair et al., 2019). Then, the significance and relevance of the structural model relationships were analyzed. Because the interaction terms were created using a two-stage approach, analysis of the main effects was initially executed without the moderator (Hair et al., 2017). Findings from the bootstrapping procedure (Streukens and Leroi-Werelds, 2016) are shown in Table 4.

Overall, the findings support the hypotheses related to the positive effect of IT capabilities on cross-border e-commerce strategic performance $(H 1)$ and financial performance (H2). In contrast, the hypotheses related to the positive effects of international marketing capabilities ( $H 3$ and $H 4$ ) and export operations capabilities ( $H 5$ and $H 6$ ) on crossborder e-commerce performance were not supported. Contrary to expectations, the analysis revealed a significantly negative effect of export operations capabilities on cross-border e-commerce financial performance (path coefficient of -0.243). Possible explanations for this result are presented in the discussion section below. The findings support $H 7$, confirming the positive relationship between e-commerce strategic performance and financial performance. With respect to the moderating effects of the use of third-party platforms, only $H 8 b$ was supported. In fact, the findings show that the use of third-party e-commerce platforms negatively moderates the relationship between IT capabilities and cross-border e-commerce financial performance. All other hypotheses ( $\mathrm{H} 8 \mathrm{a}, \mathrm{H} 9 \mathrm{a}, \mathrm{H} 9 \mathrm{~b}, \mathrm{H} 1 \mathrm{Oa}, \mathrm{H} \mathrm{OOb})$ are rejected. However, contrary to expectations, the analysis highlights a significant positive 


\begin{tabular}{|c|c|c|c|c|c|c|c|c|}
\hline $\mathrm{HP}$ & Path & Path coeff. & $t$-Statistic & $p$-Value & $\begin{array}{c}2.5 \% \\
\text { Confidence } \\
\text { interval }\end{array}$ & $\begin{array}{l}97.5 \% \\
\text { Confidence } \\
\text { interval }\end{array}$ & Decision & e-commerce \\
\hline$H 1$ & $\begin{array}{l}\text { IT capabilities } \rightarrow \text { E-commerce strategic } \\
\text { performance }\end{array}$ & 0.408 & 3.629 & $0.000 * *$ & $* \quad 0.175$ & 0.617 & Supported & \\
\hline H2 & $\begin{array}{l}\text { IT capabilities } \rightarrow \text { E-commerce financial } \\
\text { performance }\end{array}$ & 0.501 & 4.592 & $0.000 * *$ & 0.307 & 0.739 & Supported & \\
\hline$H 3$ & $\begin{array}{l}\text { International marketing capabilities } \\
\rightarrow \text { E-commerce strategic performance }\end{array}$ & 0.180 & 1.249 & 0.212 & -0.125 & 0.443 & Rejected & 277 \\
\hline H4 & $\begin{array}{l}\text { International marketing capabilities } \rightarrow \\
\text { E-commerce financial performance }\end{array}$ & -0.284 & 1.826 & 0.068 & -0.586 & 0.029 & Rejected & \\
\hline H5 & $\begin{array}{l}\text { Export operations capabilities } \rightarrow \\
\text { E-commerce strategic performance }\end{array}$ & 0.043 & 0.288 & 0.774 & -0.265 & 0.317 & Rejected & \\
\hline H6 & $\begin{array}{l}\text { Export operations capabilities } \rightarrow \\
\text { E-commerce financial performance }\end{array}$ & -0.243 & 2.167 & $0.030^{*}$ & -0.447 & -0.005 & Rejected & \\
\hline$H 7$ & $\begin{array}{l}\text { E-commerce strategic performance } \rightarrow \\
\text { E-commerce financial performance }\end{array}$ & 0.264 & 2.909 & $0.004^{* *}$ & 0.057 & 0.418 & Supported & \\
\hline$H 8 a$ & $\begin{array}{l}\text { Platforms*IT capabilities } \rightarrow \\
\text { E-commerce strategic performance }\end{array}$ & 0.000 & 0.002 & 0.999 & -0.191 & 0.286 & Rejected & \\
\hline$H 8 b$ & $\begin{array}{l}\text { Platforms*IT capabilities } \rightarrow \\
\text { E-commerce financial performance }\end{array}$ & -0.187 & 2.211 & $0.027^{*}$ & -0.340 & -0.011 & Supported & \\
\hline$H 9 a$ & $\begin{array}{l}\text { Platforms*International marketing } \\
\text { capabilities } \rightarrow \text { E-commerce strategic } \\
\text { performance }\end{array}$ & 0.273 & 1.159 & 0.246 & -0.307 & 0.589 & Rejected & \\
\hline$H 9 b$ & $\begin{array}{l}\text { Platforms*International marketing } \\
\text { capabilities } \rightarrow \text { E-commerce financial } \\
\text { performance }\end{array}$ & -0.155 & 0.944 & 0.345 & -0.444 & 0.199 & Rejected & \\
\hline $\mathrm{H1Oa}$ & $\begin{array}{l}\text { Platforms*Export operations } \\
\text { capabilities } \rightarrow \text { E-commerce strategic } \\
\text { performance }\end{array}$ & -0.105 & 0.912 & 0.362 & -0.280 & 0.177 & Rejected & \\
\hline $\mathrm{H1Ob}$ & $\begin{array}{l}\text { Platforms*Export operations } \\
\text { capabilities } \rightarrow \text { E-commerce financial } \\
\text { performance }\end{array}$ & 0.300 & 3.449 & $0.001^{* *}$ & 0.125 & 0.471 & Rejected & \\
\hline \multicolumn{2}{|c|}{ Control variables } & $\begin{array}{l}\text { Path } \\
\text { coeff. }\end{array}$ & $t$-Statistic & $\begin{array}{c}p- \\
\text { Value }\end{array}$ & $\begin{array}{l}2.5 \% \\
\text { Confidence } \\
\text { interval }\end{array}$ & $\begin{array}{l}97.5 \% \\
\text { Confidence } \\
\text { interval }\end{array}$ & Significance & \\
\hline \multicolumn{2}{|c|}{$\begin{array}{l}\text { International experience } \rightarrow \text { E-commerce strategic } \\
\text { performance }\end{array}$} & -0.070 & 0.695 & 0.487 & -0.308 & 0.092 & Not sig. & \\
\hline \multicolumn{2}{|c|}{$\begin{array}{l}\text { International experience } \rightarrow \text { E-commerce financial } \\
\text { performance }\end{array}$} & -0.071 & 0.973 & 0.331 & -0.204 & 0.082 & Not sig. & \\
\hline \multicolumn{2}{|c|}{$\begin{array}{l}\text { International experience } \rightarrow \text { Export operations } \\
\text { capabilities }\end{array}$} & 0.352 & 3.827 & $0.000 * *$ & 0.130 & 0.496 & Sig. & \\
\hline \multicolumn{2}{|c|}{ International experience $\rightarrow$ IT capabilities } & 0.107 & 0.925 & 0.355 & -0.165 & 0.290 & Not sig. & \\
\hline \multicolumn{2}{|c|}{$\begin{array}{l}\text { International experience } \rightarrow \text { International marketing } \\
\text { capabilities }\end{array}$} & 0.346 & 4.800 & $0.000^{* *}$ & 0.175 & 0.463 & Sig. & \\
\hline \multicolumn{2}{|c|}{$\begin{array}{l}\text { E-commerce experience } \rightarrow \text { E-commerce strategic } \\
\text { performance }\end{array}$} & 0.150 & 1.531 & 0.126 & -0.047 & 0.335 & Not sig. & \\
\hline \multicolumn{2}{|c|}{$\begin{array}{l}\text { E-commerce experience } \rightarrow \text { E-commerce financial } \\
\text { performance }\end{array}$} & 0.118 & 1.275 & 0.202 & -0.077 & 0.286 & Not sig. & \\
\hline \multicolumn{2}{|c|}{$\begin{array}{l}\text { E-commerce experience } \rightarrow \text { Export operations } \\
\text { capabilities }\end{array}$} & -0.094 & 0.887 & 0.375 & -0.301 & 0.113 & Not sig. & Table 4. \\
\hline \multirow{2}{*}{\multicolumn{2}{|c|}{$\begin{array}{l}\text { E-commerce experience } \rightarrow \text { IT capabilities } \\
\text { E-commerce experience } \rightarrow \text { International marketing } \\
\text { capabilities }\end{array}$}} & 0.143 & 1.319 & 0.187 & -0.081 & 0.337 & Not sig. & e testing \\
\hline & & g $\quad-0.013$ & 0.106 & 0.916 & -0.260 & 0.216 & Not sig. & $\begin{array}{r}\text { results of the } \\
\text { structural model path }\end{array}$ \\
\hline \multicolumn{2}{|c|}{ Notes: $* p<0.05 ; * * p<0.01 ; \mathrm{HP}=$ hypothesis } & & & & & & & coefficients \\
\hline
\end{tabular}


RIBS

32,2

moderating effect of the use of third-party e-commerce platforms on the relationship between export operations capabilities and e-commerce financial performance. These results are discussed in the following section.

Finally, with respect to the effect of control variables, both international marketing and export operations capabilities, but not IT capabilities, are positively related to exporters' international experience. Experience with cross-border e-commerce was not significantly related to any variable.

\section{Discussion}

This study contributes to the knowledge on the drivers of exporters' cross-border e-commerce performance. Unlike previous analyzes, this study specifically examined small and medium-sized exporters and focused on e-commerce as a foreign market entry mode rather than as a supplement to offline exporting activities. Overall, this research extends the previous knowledge on the links between export capabilities and foreign market performance. Our study highlights the positive effects of IT capabilities on cross-border e-commerce strategic and financial performance. This result extends previous findings about the effects of IT capabilities on overall performance in the foreign market (Gregory et al., 2019; Murray et al., 2011).

With respect to export operations capabilities, the analysis showed unexpected results. Contrary to previous findings on the positive effect of similar capabilities on foreign market performance in general (Kaleka, 2012; Morgan et al., 2012), we found that export operations capabilities had a negative effect on financial performance. This may be related to the specific nature of the sample firms, all of which had entered the foreign market via multiple entry modes (mainly importers and distributors) and had only recently adopted cross-border e-commerce as an additional channel. Exporters that have previously developed advanced operational capabilities may be more likely to continue preferring traditional entry modes. Therefore, they may report lower crossborder e-commerce sales as a percentage of total export sales (i.e. lower financial performance). Results related to the control variables seem to corroborate this interpretation. In fact, firms with longer international experience also had a higher level of international export operations capabilities. In sum, cross-border e-commerce may be viewed as a pure sales channel, requiring only IT capabilities.

This research also enriches the available knowledge on cross-border e-commerce by acknowledging the effects of the use of third-party platforms (e.g. Amazon and Alibaba). While previous research shows that exporters are increasingly using third-party platforms, it has not explored the effects of this choice on the relationship between firms' capabilities and their performance (Deng and Wang, 2016; Wang et al., 2020). We found that the use of third-party e-commerce platforms weakens the relationship between a firm's IT capabilities and its performance. Even firms with a low level of IT capabilities can obtain satisfactory cross-border e-commerce financial performance when using third-party platforms. We also found an unexpected positive moderating role of the use of third-party platforms on the relationship between export operations capabilities and e-commerce financial performance. The use of external platforms emphasized the effects of export operations capabilities. This result may be related to the global reach of cross-border e-commerce platforms. In other words, when using third-party platforms, exporters may receive orders from all over the world, thus experience a greater variety and complexity of legal and fiscal requirements. In these cases, operations capabilities are a significant driver of performance. 


\section{Managerial implications}

The findings of this research offer several practical insights to exporting SMEs. First, to successfully adopt cross-border e-commerce, SMEs need to develop IT capabilities. Moreover, because a firm's IT capabilities are not related to its previous experience with foreign markets, firms need to specifically invest in IT. At the same time, firms should avoid the so-called "virtuality trap" (Sinkovics et al., 2013) - in other words, relying too much on external e-commerce channels may prevent SMEs from learning about foreign markets. Digital international market entry strategies do not allow interpersonal interactions, which is a significant drawback (Watson et al., 2018). Moreover, even if international marketing capabilities are not related to e-commerce performance, firms are likely to use foreign market knowledge previously acquired through offline channels (e.g. through direct interactions with distributors and importers). Therefore, while cross-border e-commerce may accelerate overall export performance, export managers are urged to approach it strategically and with a clear medium-term view to develop the required capabilities. This suggestion specifically applies to the many SMEs that, driven by the COVID-19 crisis, are embracing the opportunities offered by cross-border e-commerce without the needed planning. While such a reactive approach may result in a rapid increase in foreign sales, a proactive strategy is needed to experience sustainable growth in the international market. A proactive strategy also encompasses clear decisions about the relationships between crossborder e-commerce and other offline entry modes to prevent conflicts between channels (particularly distributors and importers). Deciding whether to use a third-party cross-border e-commerce platform and selecting the most suitable one will also affect sales, prices and margins and customer perceptions about the brand. Moreover, communications must be designed in such a way that they are noticed by customers in the cross-border e-commerce environment, where the number of competitors is growing rapidly. The volume of work and capabilities required to strategically manage cross-border e-commerce may motivate firms to hire or collaborate with specialists (e.g. temporary export managers or digital export managers). Trade promotions organizations can also support SMEs in their cross-border e-commerce efforts, such as by establishing specific agreements with cross-border e-commerce platforms and designing training services.

\section{Conclusion}

While many SMEs are rapidly embracing cross-border e-commerce as a new foreign market entry mode, theoretical and managerial knowledge on its success factors is limited. The results of this research highlight the varied effects of export capabilities on cross-border e-commerce performance. In particular, they reveal the role of the exporter's IT capabilities and that the use of third-party cross-border e-commerce platforms may mitigate the positive effect of these capabilities. The findings also suggest that SMEs with strong export operations capabilities may prefer traditional entry modes such as offline partnerships with importers and distributors.

Given that cross-border e-commerce is a nascent phenomenon (UNCTAD, 2017), caution is recommended when interpreting these findings. In particular, most of the exporters participating in this study had only recently implemented cross-border e-commerce; thus, longitudinal data on its success factors are absent. Therefore, it is not possible to evaluate whether export capabilities have different effects in the short versus the long term. Therefore, future longitudinal studies would be extremely valuable.

This study has several other limitations. First, data were collected from exporters in the food and beverage industry only. While this industry (together with fashion) accounts for the largest component of Italian B2C cross-border e-commerce, it also presents some specific
Cross-border e-commerce 
RIBS

32,2

280

features. In particular, food and beverage products are highly standardized, thus do not require intense interactions between exporters and customers. This may partly explain the insignificant effect of international marketing capabilities on strategic performance. However, the findings may differ in industries in which interactions with international customers play a stronger role and require higher relationship management capabilities. The sample size, while being adequate for an exploratory analysis such as PLS-SEM, represents a further limitation. Collecting data from a larger sample of exporters adopting cross-border e-commerce would also advance the knowledge through multigroup analyzes. For example, model estimations for small versus medium-sized exporters or for exporters from different countries could be compared. Our study comprised SMEs, which have specific exporting challenges (Morais and Ferreira, 2020; Paul et al., 2017). Respondents were mainly managers of marketing and sales departments, who may have a different view from, for example, IT managers. Moreover, this study included exporters using both traditional foreign market entry modes and cross-border e-commerce. It was not possible to assess whether this was the result of participant self-selection or whether it was related specifically to the food and beverage industry, which is characterized by more traditional firms compared with more innovative industries. Future studies should explore the effects of the export capabilities of firms using only cross-border e-commerce. In addition, the combined effects of export capabilities and other types of capabilities such as market orientation should be researched (Fernandes et al., 2020). Finally, the role and effects of different types of e-commerce platforms could be examined.

\section{References}

Alarcón-del-Amo, M-D-C., Rialp-Criado, A. and Rialp-Criado, J. (2018), "Examining the impact of managerial involvement with social media on exporting firm performance", International Business Review, Vol. 27 No. 2, pp. 355-366.

Andersen, O. (1997), "Internationalization and market entry mode: a review of theories and conceptual frameworks", MIR: Management International Review, Vol. 37 No. 2, pp. 27-42.

Armstrong, J.S. and Overton, T.S. (1977), "Estimating nonresponse bias in mail surveys", Journal of Marketing Research, Vol. 14 No. 3, pp. 396-402.

Barney, J. (1991), "Firm resources and sustained competitive advantage", Journal of Management, Vol. 17 No. 1, pp. 99-120.

Bianchi, C. and Mathews, S. (2016), "Internet marketing and export market growth in Chile", Journal of Business Research, Vol. 69 No. 2, pp. 426-434.

Bianchi, C., Glavas, C. and Mathews, S. (2017), "SME international performance in Latin America: the role of entrepreneurial and technological capabilities", Journal of Small Business and Enterprise Development, Vol. 24 No. 1, pp. 176-195.

Chen, J., Sousa, C.M. and He, X. (2016), "The determinants of export performance: a review of the literature 2006-2014", International Marketing Review, Vol. 33 No. 5, pp. 626-670.

Day, G.S. (1994), "The capabilities of market-driven organizations", Journal of Marketing, Vol. 58 No. 4, pp. 37-52.

Deng, Z. and Wang, Z. (2016), "Early-mover advantages at cross-border business-to-business e-commerce portals", Journal of Business Research, Vol. 69 No. 12, pp. 6002-6011.

Efrat, K., Hughes, P., Nemkova, E., Souchon, A.L. and Sy-Changco, J. (2018), "Leveraging of dynamic export capabilities for competitive advantage and performance consequences: evidence from China”, Journal of Business Research, Vol. 84, pp. 114-124.

Ellram, L.M. (1991), "Key success factors and barriers in international purchasing partnerships", Management Decision, Vol. 29 No. 7, pp. 38-44. 
Fernandes, C.I., Ferreira, J.J., Lobo, C.A. and Raposo, M. (2020), "The impact of market orientation on the internationalisation of SMEs", Review of International Business and Strategy, Vol. 30 No. 1, pp. 123-143.

Ferreira, J.J., Teixeira, S.J. and Rammal, H.G. (2021), "Technological innovation and international competitiveness for business growth. Challenges and opportunities", in Technological Innovation and International Competitiveness for Business Growth, Palgrave Macmillan, Switzerland, pp. 1-14.

Gabrielsson, M. and Gabrielsson, P. (2011), "Internet-based sales channel strategies of born global firms”, International Business Review, Vol. 20 No. 1, pp. 88-99.

Geisser, S. (1974), "A predictive approach to the random effect model”, Biometrika, Vol. 61 No. 1, pp. 101-107.

Giuffrida, M., Mangiaracina, R., Perego, A. and Tumino, A. (2017), "Cross-border B2C e-commerce to greater China and the role of logistics: a literature review", International Journal of Physical Distribution and Logistics Management, Vol. 47 No. 9, pp. 772-795.

Glavas, C., Mathews, S. and Bianchi, C. (2017), "International opportunity recognition as a critical component for leveraging internet capabilities and international market performance", Journal of International Entrepreneurship, Vol. 15 No. 1, pp. 1-35.

Glavas, C., Mathews, S. and Russell-Bennett, R. (2019), "Knowledge acquisition via internet-enabled platforms: examining incrementally and non-incrementally internationalizing SMEs", International Marketing Review, Vol. 36 No. 1, pp. 74-107.

Goldman, S.P., van Herk, H., Verhagen, T. and Weltevreden, J.W. (2020), "Strategic orientations and digital marketing tactics in cross-border e-commerce: comparing developed and emerging markets", International Small Business Journal, pp. 1-22.

Gregory, G., Karavdic, M. and Zou, S. (2007), "The effects of e-commerce drivers on export marketing strategy", Journal of International Marketing, Vol. 15 No. 2, pp. 30-57.

Gregory, G.D., Ngo, L.V. and Karavdic, M. (2019), "Developing e-commerce marketing capabilities and efficiencies for enhanced performance in business-to-business export ventures", Industrial Marketing Management, Vol. 78, pp. 146-157.

Hair, J.F., Ringle, C.M. and Sarstedt, M. (2011), "PLS-SEM: indeed a silver bullet", Journal of Marketing Theory and Practice, Vol. 19 No. 2, pp. 139-151.

Hair, J.F., Hult, G.T.M., Ringle, C.M. and Sarstedt, M. (2017), A Primer on Partial Least Squares Structural Equation Modeling (PLS-SEM), Sage, Thousand Oaks, CA.

Hair, J.F., Risher, J.J., Sarstedt, M. and Ringle, C.M. (2019), "When to use and how to report the results of PLS-SEM”, European Business Review, Vol. 31 No. 1, pp. 2-24.

Hair, J.F., Hult, T.M., Ringle, C., Sarstedt, M., Magno, F., Cassia, F. and Scafarto, F. (2020), Le Equazioni Strutturali Partial Least Squares. Introduzione Alla PLS-SEM, FrancoAngeli, Milano.

Hessels, J. and Terjesen, S. (2010), "Resource dependency and institutional theory perspectives on direct and indirect export choices", Small Business Economics, Vol. 34 No. 2, pp. 203-220.

Hooper, A. and Holtbrügge, D. (2020), "Blockchain technology in international business: changing the agenda for global governance", Review of International Business and Strategy, Vol. 30 No. 2, pp. $183-200$.

ICE-ITA (2020), "E-commerce e nuove tecnologie: un traino per l'export italiano. Rapporto ICE 20192020", available at: https://www.ice.it/it/sites/default/files/inline-files/01_Rapporto\%20ICE\% 20EXPORT_2407_web.pdf (accessed 8 January 2021).

Jin, B. and Cho, H.J. (2018), "Examining the role of international entrepreneurial orientation, domestic market competition, and technological and marketing capabilities on SME's export performance", Journal of Business and Industrial Marketing, Vol. 33 No. 5, pp. 585-598. 
RIBS

32,2

Kaleka, A. (2012), "Studying resource and capability effects on export venture performance", Journal of World Business, Vol. 47 No. 1, pp. 93-105.

McCracken, G. (1988), The Long Interview, Sage, Newbury Park, CA.

Magnani, G. and Zucchella, A. (2020), "A model of entrepreneurial internationalisation in uncertain foreign environments: smaller firms and the global niche strategy", Sinergie Italian Journal of Management, Vol. 38 No. 3, pp. 23-50.

Mathews, S., Bianchi, C., Perks, K.J., Healy, M. and Wickramasekera, R. (2016), "Internet marketing capabilities and international market growth", International Business Review, Vol. 25 No. 4, pp. 820-830.

Moalla, E. and Mayrhofer, U. (2020), "How does distance affect market entry mode choice? Evidence from French companies”, European Management Journal, Vol. 38 No. 1, pp. 135-145.

Morais, F. and Ferreira, J.J. (2020), "SME internationalisation process: key issues and contributions, existing gaps and the future research agenda", European Management Journal, Vol. 38 No. 1, pp. 62-77.

Morgan, N.A., Feng, H. and Whitler, K.A. (2018), "Marketing capabilities in international marketing", Journal of International Marketing, Vol. 26 No. 1, pp. 61-95.

Morgan, N.A., Kaleka, A. and Katsikeas, C.S. (2004), "Antecedents of export venture performance: a theoretical model and empirical assessment”, Journal of Marketing, Vol. 68 No. 1, pp. 90-108.

Morgan, N.A., Katsikeas, C.S. and Vorhies, D.W. (2012), "Export marketing strategy implementation, export marketing capabilities, and export venture performance", Journal of the Academy of Marketing Science, Vol. 40 No. 2, pp. 271-289.

Murray, J.Y., Gao, G.Y. and Kotabe, M. (2011), "Market orientation and performance of export ventures: the process through marketing capabilities and competitive advantages", Journal of the Academy of Marketing Science, Vol. 39 No. 2, pp. 252-269.

Organisation for Economic Co-operation and Development (2013), "OECD glossary of statistical terms", available at: $\mathrm{https} / / /$ stats.oecd.org/glossary/detail.asp?ID=4721 (accessed 10 January 2021).

Paul, J., Parthasarathy, S. and Gupta, P. (2017), "Exporting challenges of SMEs: a review and future research agenda", Journal of World Business, Vol. 52 No. 3, pp. 327-342.

Prasad, V.K., Ramamurthy, K. and Naidu, G. (2001), "The influence of internet-marketing integration on marketing competencies and export performance", Journal of International Marketing, Vol. 9 No. 4, pp. 82-110.

Qi, X., Chan, J.H., Hu, J. and Li, Y. (2020), "Motivations for selecting cross-border e-commerce as a foreign market entry mode", Industrial Marketing Management, Vol. 89, pp. 50-60.

Ren, H., Gray, B. and Kim, K. (2009), "Performance of international joint ventures: what factors really make a difference and how?", Journal of Management, Vol. 35 No. 3, pp. 805-832.

Richter, N.F., Sinkovics, R.R., Ringle, C.M. and Schlaegel, C. (2016), "A critical look at the use of SEM in international business research", International Marketing Review, Vol. 33 No. 3, pp. 376-404.

Ringle, C.M., Wende, S. and Becker, J.M. (2015), “SmartPLS”, Bönningstedt, Vol. 3, in SmartPLS.

Shah, S.K. and Corley, K.G. (2006), "Building better theory by bridging the quantitative-qualitative divide", Journal of Management Studies, Vol. 43 No. 8, pp. 1821-1835.

Sheth, J.N. and Sharma, A. (2005), "International e-marketing: opportunities and issues", International Marketing Review, Vol. 22 No. 6, pp. 611-622.

Sinkovics, N., Sinkovics, R.R. and Jean, R.J.B. (2013), "The internet as an alternative path to internationalization?", International Marketing Review, Vol. 30 No. 2, pp. 130-155.

Spyropoulou, S., Katsikeas, C.S., Skarmeas, D. and Morgan, N.A. (2018), "Strategic goal accomplishment in export ventures: the role of capabilities, knowledge, and environment", Journal of the Academy of Marketing Science, Vol. 46 No. 1, pp. 109-129. 
Stone, M. (1974), "Cross-validatory choice and assessment of statistical predictions", Journal of the Royal Statistical Society: Series B (Methodological), Vol. 36 No. 2, pp. 111-147.

Streukens, S. and Leroi-Werelds, S. (2016), "Bootstrapping and PLS-SEM: a step-by-step guide to get more out of your bootstrap results", European Management Journal, Vol. 34 No. 6, pp. 618-632.

Trainor, K.J., Rapp, A., Beitelspacher, L.S. and Schillewaert, N. (2011), "Integrating information technology and marketing: an examination of the drivers and outcomes of e-Marketing capability", Industrial Marketing Management, Vol. 40 No. 1, pp. 162-174.

UNCTAD (2017), "Information economy report 2017. Digitalization, trade and development", available at: https://unctad.org/en/PublicationsLibrary/ier2017_en.pdf (accessed 15 December 2020).

UNCTAD (2020), "Global e-commerce hits $\$ 25.6$ trillion - latest UNCTAD estimates", available at: https:/unctad.org/news/global-e-commerce-hits-256-trillion-latest-unctad-estimates (accessed 10 January 2021).

Wang, S., Cavusoglu, H. and Deng, Z. (2016), "Early mover advantage in e-commerce platforms with low entry barriers: the role of customer relationship management capabilities", Information and Management, Vol. 53 No. 2, pp. 197-206.

Wang, Y., Jia, F., Schoenherr, T., Gong, Y. and Chen, L. (2020), "Cross-border e-commerce firms as supply chain integrators: the management of three flows", Industrial Marketing Management, Vol. 89, pp. 72-88.

Watson, G.F., IV, Weaven, S., Perkins, H., Sardana, D. and Palmatier, R.W. (2018), "International market entry strategies: relational, digital, and hybrid approaches", Journal of International Marketing, Vol. 26 No. 1, pp. 30-60.

Yamin, M. and Sinkovics, R.R. (2006), "Online internationalisation, psychic distance reduction and the virtuality trap", International Business Review, Vol. 15 No. 4, pp. 339-360.

Zhu, W., Mou, J. and Benyoucef, M. (2019), "Exploring purchase intention in cross-border E-commerce: a three stage model”, Journal of Retailing and Consumer Services, Vol. 51, pp. 320-330.

Zou, S., Taylor, C.R. and Osland, G.E. (1998), "The EXPERF scale: a cross-national generalized export performance measure”, Journal of International Marketing, Vol. 6 No. 3, pp. 37-58.

\section{Corresponding author}

Fabio Cassia can be contacted at: fabio.cassia@univr.it

For instructions on how to order reprints of this article, please visit our website:

www.emeraldgrouppublishing.com/licensing/reprints.htm

Or contact us for further details: permissions@emeraldinsight.com 